\title{
8 \\ Evaluation of Stormwater Retrofit Options for Mimico Creek Watershed
}

\author{
James Li and Kosta Kyriopoulous
}

One of the major water pollution sources in the fully urbanized Mimico Creek watershed is storm runoff. In order to control stormwater quality, retrofit stormwater management practices (RSWMPs) should be implemented. This chapter documents a study which focuses on the evaluation of appropriate RSWMPs for the Mimico Creek watershed. These practices are selected based upon physical site constraints, cost-effectiveness, and the potential to be incorporated into municipal capital works and maintenance programs. Using a derived probabilistic rainfall-runoff model and a treatment train efficiency model, the cumulative reduction of runoff volume and solids loading of a series of appropriate RSWMPs are determined to be $7 \%$ and $18 \%$ respectively. In the Mimico Creek watershed, the descending order of cost-effectiveness is: (i) downspout disconnection; (ii) water quality ponds; (iii) stormwater exfiltration systems; and (iv) oil/grit separators. Thus, the sequence of RSWMP implementation should follow the descending order of cost-effectiveness.

\subsection{Introduction}

The Mimico Creek watershed, which drains about $80 \mathrm{~km}^{2}$ of land from the cities of Toronto, Mississauga, and Brampton, has undergone significant land use changes over the last 50 years. Currently, the watershed is almost fully urbanized. With the concern over degraded water quality, a master watershed plan is being conducted by the City of Toronto. This chapter documents a study at Ryerson Polytechnic University which focuses on the evaluation of stormwater management retrofit options for the Mimico Creek watershed.

Li, J. and K. Kyriopoulous. 2002. "Evaluation of Stormwater Retrofit Options for Mimico Creek Watershed." Journal of Water Management Modeling R208-08. doi: 10.14796/JWMM.R208-08. (C) CHI 2002 www.chijournal.org ISSN: 2292-6062 (Formerly in Best modeling practices for Urban Water Systems. ISBN: 0-9683681-6-6) 


\subsection{Watershed Characteristics}

Mimico Creek comprises two upper tributaries and one main lower creek as indicated in Figure 8.1. The surficial geology of the watershed is predominately fine clay soil in the upper tributaries, till and sandy soil in the lower creek. Currently, approximately $77 \%$ of the watershed is urbanized. The primary land uses are industrial and residential. In the City of Toronto portion of the Mimico Creek, there are no specific stormwater management measures and runoff is discharged directly into the Creek. On the other hand, the upper tributaries in the cities of Mississauga and Brampton have nine stormwater management ponds. Of these, four are flood control ponds, two are water quality ponds, and three are combined quantity/quality ponds. Nevertheless, it is widely recognized that stormwater quality should be improved in the watershed.

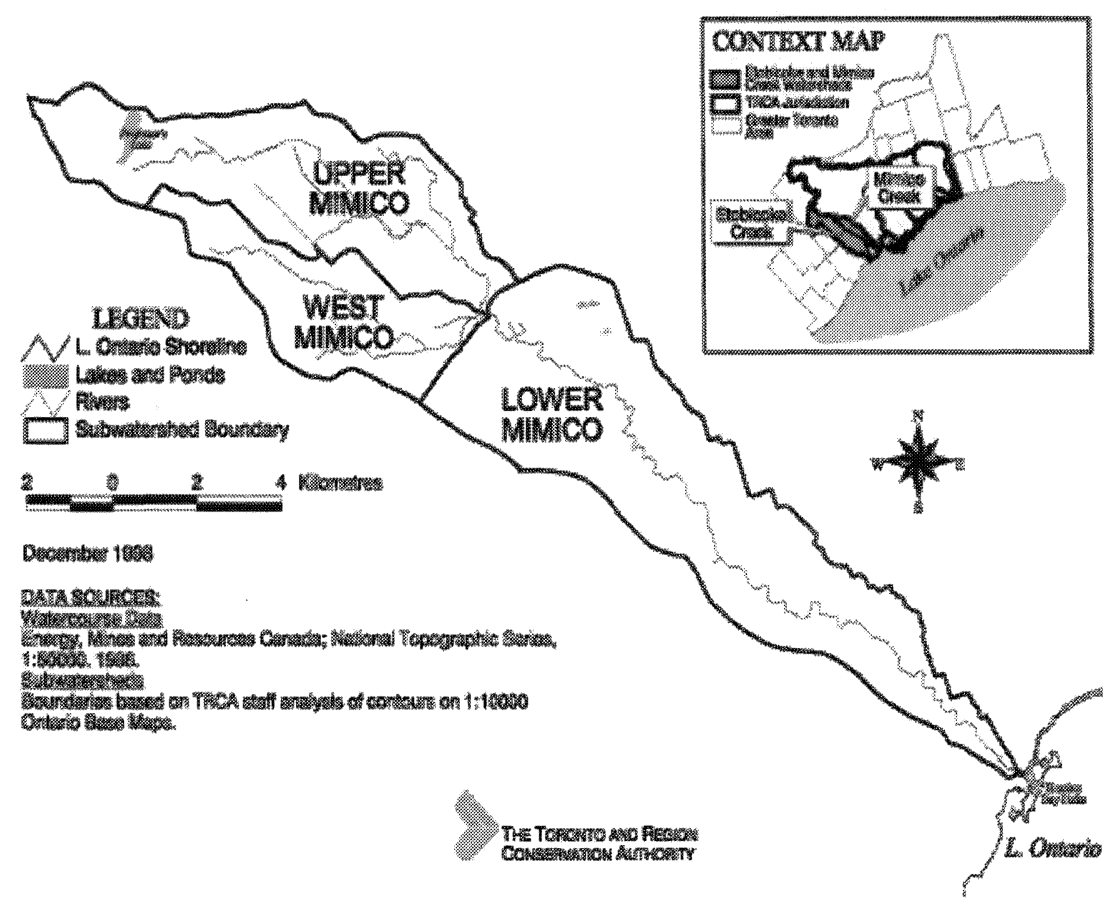

Figure 8.1 Mimico Creek watershed. 


\subsection{Stormwater Retrofit Planning}

Urbanized municipalities can play an important role in controlling urban runoff quality. However, they are faced with the following physical and financial constraints:

- lack of available space,

- lack of funding for RSWMP,

- difficulties associated with existing infrastructure systems and drainage pathways,

- lack of proven technologies available for retrofit applications,

- lack of appropriate planning strategy, and

- safety and liability issues.

As a result, it is a challenge to develop stormwater retrofit plans for urbanized watersheds. Li and Banting (1999) developed a planning tool to assist urbanized municipalities in planning stormwater retrofit options. This planning tool comprises five steps:

- development of measurable retrofit objectives,

- identification of retrofit stormwater management practices,

- formulation of alternative stormwater retrofit strategies,

- evaluation of control performance of stormwater retrofit strategies, and

- selection of preferred stormwater retrofit strategy.

The planning tool was employed to evaluate stormwater retrofit options for the Mimico Creek watershed.

\subsection{Stormwater Retrofit Planning for the Mimico Creek Watershed}

\subsubsection{Stormwater Retrofit Goals and Objectives}

The Toronto and Region Conservation Authority has developed a remedial action plan in which it strives to improve the current status of the Mimico Creek watershed (TRCA, 1998). The objectives are:

- healthier aquatic communities;

- reduce fish consumption advisories;

- reduce erosion impacts on habitats and property;

- re-establish a natural hydrologic cycle;

- re-establish and rehabilitate natural features;

- virtual elimination of toxics though pollution prevention; 
- meet guidelines for water and sediment quality;

- eliminate discharges of sanitary sewage;

- improve water quality in rivers and the lake for body contact recreation;

- improve aesthetics;

- reduce basement flooding;

- reduce infiltration and inflow to sanitary sewers; and

- eliminate or minimize threats to life and property from flooding. Based on the above objectives, the stormwater retrofit objectives selected for the Mimico Creek watershed are:

- reduce runoff volume, and

- improve water quality by the removal of pollutants from runoff.

Since no numerical control targets have been developed for the Mimico Creek watershed, the objective of this study is to investigate the maximum reduction of runoff volume and solids loading that can be achieved by applying appropriate retrofit stormwater management practices.

\subsubsection{Retrofit Stormwater Management Practices}

Selection of appropriate RSWMPs for an urbanized watershed is dependent upon physical site constraints, cost-effectiveness, and the potential to be incorporated into municipal capital works and maintenance programs. A number of RSWMPs have been tested or proposed in the Greater Toronto Area: downspout disconnection, oil/grit separators, stormwater exfiltration systems, swales and ditches, retrofit quantity ponds, stormwater quality ponds, underground stormwater tanks, and flow balancing systems. A brief description of each RSWMP follows.

\section{Downspout disconnection}

Disconnection of downspout and redirection of roof runoff to lawn areas is a source control RSWMP. By returning the roof runoff to soils through infiltration, this RSWMP reduces runoff volume and solids loadings. As storm runoff is disposed of at the lot level, it can be implemented gradually by municipalities in the form of volunteer programs or municipal by-laws. This RSWMP is suitable for a site where the local lot grading is gentle and sufficient lawn areas are available. It is also desirable to have sandy soil and a low groundwater table on the site so that the diverted runoff will not be detained on the lawn over an extended period of time. 


\section{Oil/gritseparators}

Traditional three chamber oil/grit separators are designed to capture spills and small runoff events. Recent designs have improved the capture of runoff by increasing the storage capacity and providing a washout protection mechanism for large flows. Nevertheless, only rigorous field monitoring programs can determine the effectiveness of these new designs. Although this RSWMP is primarily designed to control commercial and industrial parking lot runoff, there is no reason to prevent its use in residential areas. It can be installed under parking lots or along a road and/or sewer system which is undergoing reconstruction or rehabilitation. However, the responsibility of maintenance will fall upon the municipalities if oil/grit separators are installed along the rightof-way.

\section{Stormwater exfiltration systems}

A drainage system control RSWMP was proposed by the former city of Etobicoke to allow stormwater exfiltration along a storm sewer system ( $\mathrm{Li}$ et al. 1997). First flush runoff from catchbasins is diverted to two $200 \mathrm{~mm}$ perforated PVC pipes which are constructed below the storm sewer. As the perforated pipes are plugged at the downstream end, they store the stormwater and allow it to exfiltrate to the granular stone sewer trench and subsequently to the surrounding soils. This RSWMP can be incorporated into residential road/ storm sewer reconstruction and rehabilitation projects where the site characteristics are suitable. Thus, roads which have structural and drainage deficiency (termed "poor roads" in Table 8.1) are suitable for the application of stormwater exfiltration systems. Based on a demonstration project in the city of Etobicoke, the construction cost of the perforated pipes was estimated to be about $15 \%$ of the sewer reconstruction cost. This RSWMP is not appropriate for sites where there is concern over ground water contamination by urban runoff and spills, and damage to foundations by infiltrated water. A detailed description of the system design, construction, operation and maintenance, and effectiveness can be found at http://www.civil.ryerson.ca/urban/f-techno.html.

\section{Swales and ditches}

Alternative drainage systems such as swales and ditches have been investigated by $\mathrm{Li}$ et al (1998) and Sabourin (1997). Swales and ditches can be designed to increase detention of runoff along the drainage path and provide water quality treatment. Li et al (1998) proposed a variety of swale and ditch designs where the drainage systems are integrated with check dams and infiltration devices. Sabourin (1997) developed an evaluation procedure to determine the most 
appropriate drainage systems for new developments and retrofit situations. However, the water quality performance of swales and ditches still require confirmation from field monitoring programs. Existing ditches and swales can be considered to be an RSWMP if they are maintained properly. They are appropriate for non-erosive soil, gentle slope, wide right-of-way, and large distance between entrances.

\section{Stormwater quantity pond retrofit}

Flood control ponds may be retrofitted to provide water quality treatment functions. However, it is important to maintain the existing flood storage in the pond. In order to consider this RSWMP, there should be adequate space for the creation of a water quality cell and convenient road access for construction and regular maintenance.

\section{Stormwater quality ponds}

If sufficient land is available, stormwater quality ponds can be a feasible downstream control RSWMP. In order to be cost-effective, new stormwater quality ponds should serve a drainage area of at least 5 ha. Other suitability considerations include outfall invert elevation, road access for construction and maintenance, fish habitats, and public acceptance.

\section{Underground stormwater quality tanks/tunnels}

In highly urbanized areas, where the land suitable for a water quality pond may be very expensive and difficult to find, underground storage facilities such as tanks/tunnels may be an appropriate alternative. Although underground storage tanks have been used for the control of stormwater quantity and combined sewer overflows, they are not commonly used for stormwater quality treatment. In order to be cost-effective, several storm outfalls may be disconnected and then reconnected to an interceptor sewer which discharges to an underground stormwater tank. To enhance the settling capacity, cross flow inclined plate settlers (Dunkers, 1979) may be installed inside the tank. The treatment efficiency of this proposed RSWMP is not known and should be determined by rigorous field monitoring.

Receiving water-based flow balancing systems

This RSWMP was originally developed by Karl Dunkers of Sweden about twenty years ago. One version of the Karl Dunkers flow balancing system was implemented by the former city of Scarborough (Aquafor, 1994). As shown in Figure 8.2, the Scarborough version of Karl Dunkers flow balancing system consists of five interconnecting cells which detain runoff for the purpose of 


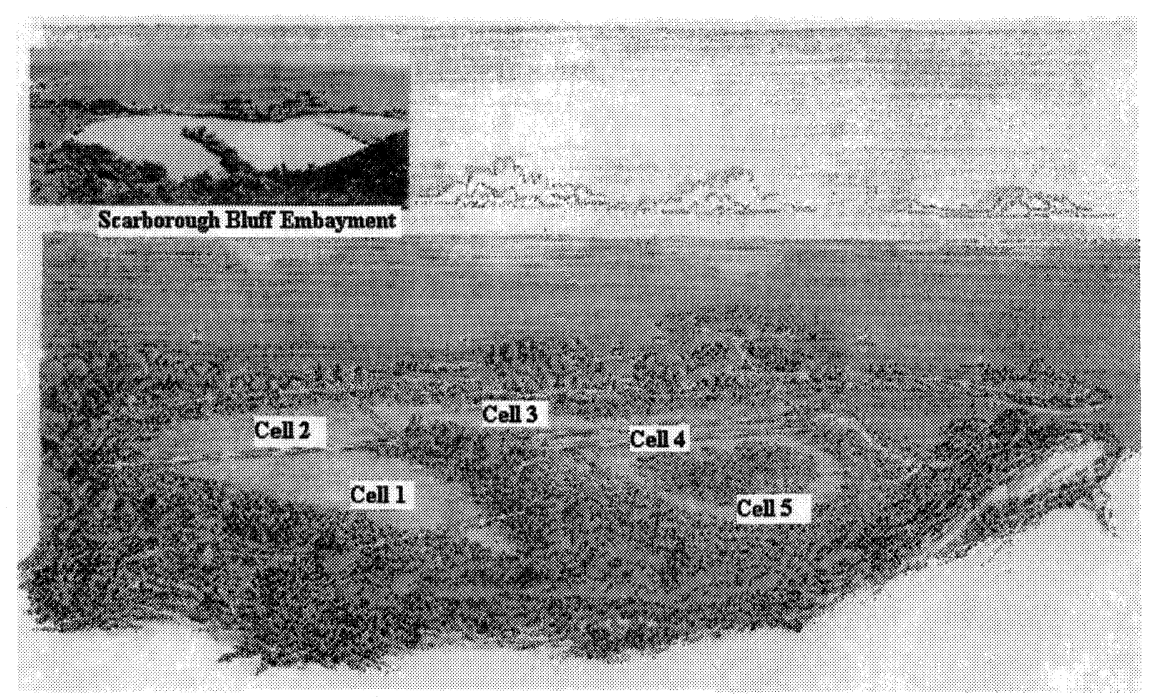

Figure 8.2 Dunkers flow balancing system.

removal of sediments and reduction of bacterial and nutrient concentrations (Paul Theil, 1991; Aquafor, 1994). These cells are separated by plastic curtains which are connected at the top to floating pontoons held in place with piles. Each plastic curtain has an opening below water which is sized for a certain level of volumetric control. Runoff enters Cell 1 and displaces the existing water into the adjacent Cell 2 which in turn displaces water into the adjacent Cell 3. For large runoff events, the flow which will exceed the capacity of the first three cells will discharge directly from Cell 3 to Lake Ontario. The captured runoff in Cells 2 and 3 will subsequently be pumped back to Cells 1,4 and 5, and ultimately be discharged to the lake. The first four cells allow settling of contaminants within the cells while Cell 4, which is relatively shallower than the previous cells, allows nutrient uptake by aquatic vegetation.

Another version of a flow balancing system was constructed by the former city of Etobicoke for the treatment of storm runoff from a motel strip re-development (Tran, 1994). This RSWMP is also a receiving water facility, which is protected by an embayment. Runoff flows through each cell and finally discharges to the receiving lake. This RSWMP may be suitable for fully urbanized areas where the land-based end-of-pipe RSWMP is not appropriate. However, it must be protected from wave and ice by an embayment or engineered breakwater. An access road for construction and maintenance (e.g. dredging) is important for successful installation and operation. The treatment efficiency of this RSWMP is not known and should be determined by rigorous field monitoring programs. 
In order to determine the appropriate RSWMPs for the Mimico Creek, suitability criteria of each RSWMP must be developed. Using the ArcView Geographic Information System (GIS) and the suitability criteria, the appropriate RSWMPs for the city of Toronto are: downspout disconnection, oil/grit separators, exfiltration systems, and water quality ponds. For the cities of Brampton and Mississauga, the appropriate RSWMPs were oil/grit separators and water quality ponds. Table 8.1 shows the suitability criteria for these RSWMPs. Using the ArcView GIS, these criteria are used to determine the appropriate locations for these RSWMP. Figure 8.3 illustrates the GIS screening procedure for new water quality ponds. Storm outfalls which are greater than $600 \mathrm{~mm}$ are first identified using the criteria in Table 8.1. Then the land use and open space areas of the associated sewersheds are determined by query functions. Figure 8.4 shows the outfall locations where water quality ponds are appropriate.

Table 8.1 Suitability criteria for RSWMPs.

\begin{tabular}{|c|c|c|}
\hline $\begin{array}{l}\text { Potential RSWMP } \\
\text { Measure }\end{array}$ & Criteria Variables & $\begin{array}{c}\text { Data Needed for Areas Satisfying } \\
\text { the Criteria }\end{array}$ \\
\hline $\begin{array}{l}\text { Downspout } \\
\text { Disconnection }\end{array}$ & $\begin{array}{l}\text { Lots with downspout connected } \\
\text { to sewers } \\
\text { Roof to lot area ratio }<0.5 \\
\text { Sandy soil } \\
\text { Residential land use }\end{array}$ & $\begin{array}{l}\text { Drainage area suitable } \\
\text { Roof area suitable } \\
\text { Number of lots suitable } \\
\text { Lots with connected downspout }\end{array}$ \\
\hline $\begin{array}{l}\text { Oil/Grit } \\
\text { Separators }\end{array}$ & $\begin{array}{l}\text { Storm sewers present } \\
\text { Industrial/commercial land use } \\
\text { Road in need of construction } \\
\text { Spill prone areas }\end{array}$ & $\begin{array}{l}\text { Industrial area suitable } \\
\text { Commercial area suitable } \\
\text { Spill location }\end{array}$ \\
\hline $\begin{array}{l}\text { Exfiltration } \\
\text { Systems }\end{array}$ & $\begin{array}{l}\text { Storm sewers present } \\
\text { Roof to lot area ratio }<0.5 \\
\text { Local roads present } \\
\text { Sandy soil } \\
\text { Residential land use }\end{array}$ & $\begin{array}{l}\text { Area suitable with good roads } \\
\text { Area suitable with poor roads } \\
\text { Length of suitable good roads } \\
\text { Length of suitable poor roads }\end{array}$ \\
\hline $\begin{array}{l}\text { Water Quality } \\
\text { Ponds }\end{array}$ & $\begin{array}{l}\text { Storm outfalls over } 600 \mathrm{~mm} \\
\text { Drainage area }>5 \text { ha. } \\
\text { Adequate space for a pond } \\
\text { Compatibility with adjacent } \\
\text { land uses outside floodplain }\end{array}$ & $\begin{array}{l}\text { Residential area served by pond } \\
\text { Commercial area served by pond } \\
\text { Industrial area served by pond }\end{array}$ \\
\hline
\end{tabular}




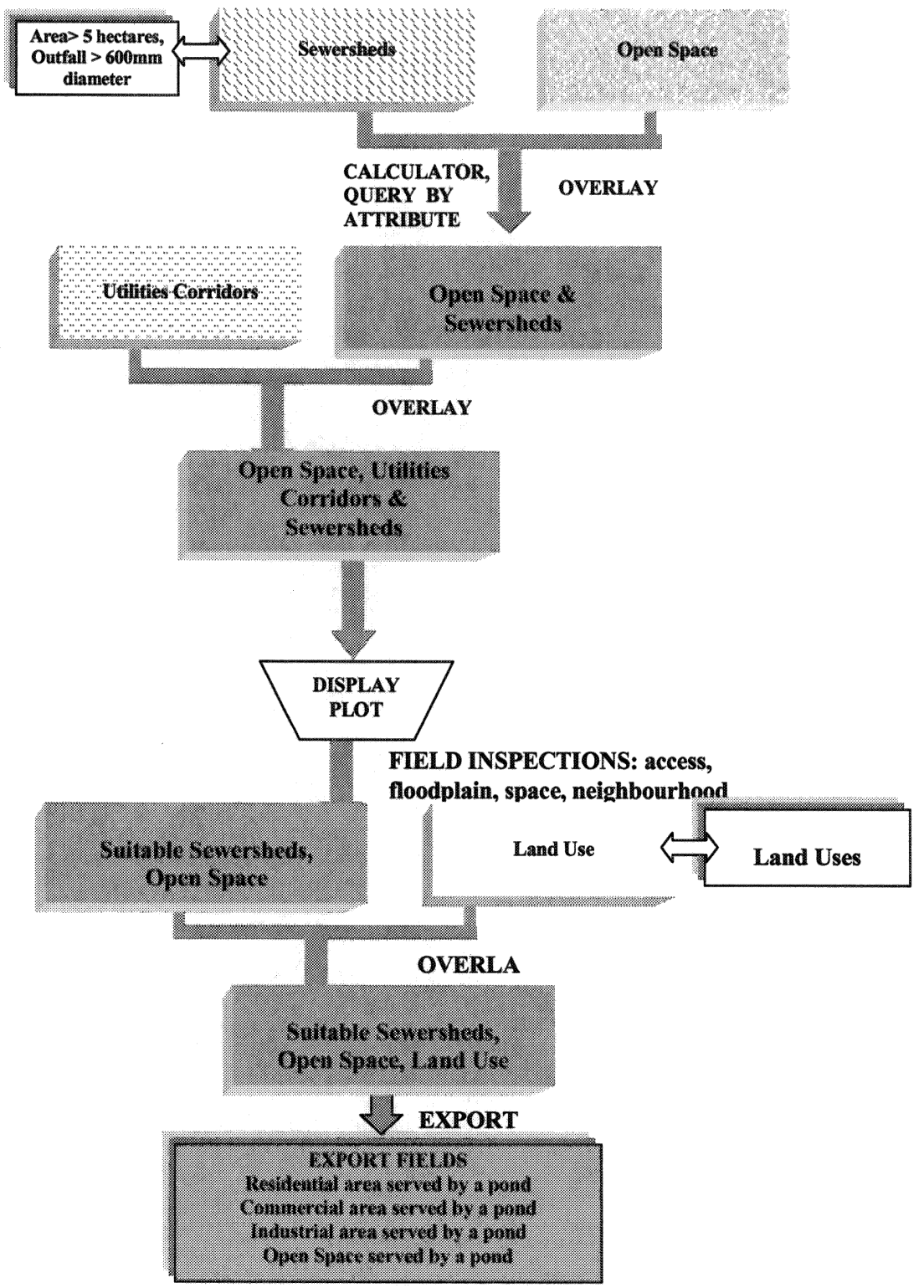

Figure 8.3 GIS screening flow diagrams for water quality ponds. 


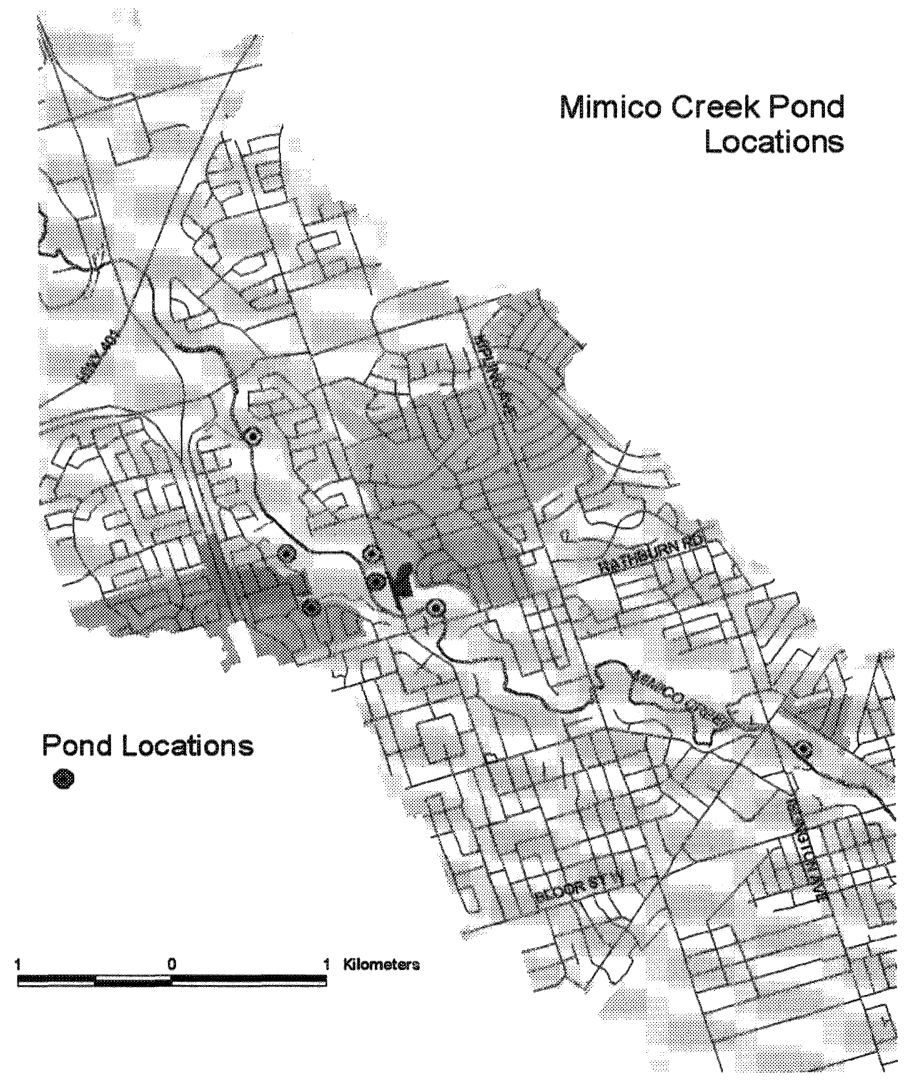

Figure 8.4 Proposed water quality ponds in the City of Toronto.

\subsubsection{Formulation of Stormwater Retrofit Strategies}

It is widely recognized that there is a preferred hierarchy of stormwater management measures which is in accord with the concept of ecosystem planning (MOEE, 1994). It is always desirable to control runoff at its source, or as close as possible before other drainage systems and downstream control measures are considered. This preferred hierarchy of retrofit stormwater management measures has advantages over the traditional downstream outlet control techniques (e.g. ponds) because it can maintain the spatial and temporal characteristics of the natural hydrologic cycle. Additionally, the preferred hierarchy, which emphasizes low cost source and drainage system controls, allows stormwater management measures to integrate with municipal capital and operating programs gradually. 
Alternative stormwater quality management strategies can be formulated by combining various mixes and magnitudes of RSWMPs in accord with the preferred hierarchy. However, the cost and effectiveness of emerging RSWMP such as oil/grit separators, stormwater exfiltration systems, stormwater tanks, flow balancing systems are not known and they must be confirmed by rigorous field monitoring programs. Thus, both short- and long-term strategies should be formulated as follows:

- Short-term strategies (e.g. 5-year implementation) may use conventional RSWMPs such as downspout disconnection, quantity pond retrofit, and water quality ponds. These 5-year planning strategies are designed to match the normal planning horizon of municipal capital works programs in the Greater Toronto Area. Thus, the recommended RSWMPs can be directly incorporated into municipal capital budget.

- Long-term strategies (e.g. 5- to 25- year implementation) may incorporate emerging RSWMPs such as oil/grit separators, stormwater exfiltration systems, stormwater tanks, flow balancing systems. It is assumed that the application potential of emerging RSWMPS will take more than five years of rigorous field monitoring programs to confirm their cost-effectiveness.

The alternative stormwater quality management strategies for the city of Toronto's portion of the Mimico watershed are shown in Table 8.2. Each strategy represents a combination of RSWMPs and was formulated by considering the preferred hierarchy of RSWMPs, the experience and knowledge of the RSWMPs, and the short and long-term implementation constraints.

Table 8.2 Alternative retrofit strategies for Mimico Creek watershed.

\begin{tabular}{|c|c|c|c|c|c|c|}
\hline Strategy & $\begin{array}{l}\text { Implemen } \\
\text {-tation } \\
\text { horizon } \\
\text { (years) }\end{array}$ & $\begin{array}{l}\% \text { Downspout } \\
\text { Disconnection }\end{array}$ & $\begin{array}{l}\% \text { Oil/grit } \\
\text { separators }\end{array}$ & $\begin{array}{c}\text { \% Retrofit } \\
\text { Exfiltration Systems } \\
\text { on poor roads }\end{array}$ & $\begin{array}{l}\% \\
\text { Exfiltration } \\
\text { Systems on } \\
\text { future poor } \\
\text { roads }\end{array}$ & $\begin{array}{c}\text { \# of New } \\
\text { Quality } \\
\text { Ponds }\end{array}$ \\
\hline \multicolumn{7}{|c|}{ Quantity control implementation strategies } \\
\hline S1a & $1-5$ & 20 & 0 & 0 & 0 & 0 \\
\hline $\mathrm{S} 2 \mathrm{a}$ & $6-15$ & 50 & 0 & 100 & 10 & 0 \\
\hline $\mathrm{S} 3 \mathrm{a}$ & $16-25$ & 100 & 0 & 100 & 20 & 0 \\
\hline \multicolumn{7}{|c|}{ Quality control implementation strategies } \\
\hline $\mathrm{S} 1 \mathrm{~b}$ & $1-5$ & 20 & 0 & 0 & 0 & 2 \\
\hline$S 2 b$ & $6-15$ & 50 & 20 & 100 & 10 & 4 \\
\hline $\mathrm{S} 3 \mathrm{~b}$ & $16-25$ & 100 & 30 & 100 & 20 & 6 \\
\hline
\end{tabular}


The percentages in the table indicate the percentages of the appropriate RSWMPs that were applied in the strategies. For instance, $100 \%$ of retrofit exfiltration systems on poor roads represent the control option where all the appropriate roads which are in poor condition now will be retrofitted with exfiltration systems.

\subsubsection{Evaluation of Stormwater Retrofit Strategies and Cost- effectiveness of RSWMPs}

Alternative stormwater quality management strategies should be evaluated with respect to their achievement of environmental and economic objectives. Selection of appropriate models for the prediction of runoff quantity and quality and RSWMP performance is dependent upon the budget, time, required level of accuracy, and the technical expertise available. Among the different types of urban drainage models, simulation models such as STORM (HEC, 1974) and SWMM (Huber and Dickinson, 1988) are the most versatile because they can model complex processes in detail and test the system response to different types of inputs and system configurations on a continuous basis. However, they sometimes require sophistication in their use and can be time consuming. Analytical probabilistic models (Adams and Bontje, 1983) and a multi-efficiency model (Weatherbe, 1995) were selected for this study because the required data and the level of accuracy are suitable for the preliminary planning of RSWMPs. These models assume an annual time scale in the analysis.

Average annual runoff volume and solids loading are estimated by the analytical probabilistic models and are given by:

$$
\begin{aligned}
& R=10 * A^{*}\left(\frac{\theta \phi}{\zeta}\right) e^{-\zeta S_{d}} \\
& L=\frac{R * C}{1000}
\end{aligned}
$$

where:

$$
\begin{aligned}
R & =\text { average annual runoff volume in } \mathrm{m} 3 / \mathrm{yr}, \\
A & =\text { drainage area in hectares, } \\
\theta & =\text { average annual number of rainfall events, } \\
\phi & =\text { area-weighted average runoff coefficient } \\
\zeta & =\text { reciprocal of average rainfall event volume }(1 / \mathrm{mm}) \\
S_{d} & =\text { area-weighted average depression storage }(\mathrm{mm}), \\
L & =\text { average annual runoff solids loading in } \mathrm{kg} / \mathrm{yr}, \text { and } \\
C & =\text { average runoff solids concentration }(\mathrm{mg} / \mathrm{L}) .
\end{aligned}
$$


For preliminary planning level analysis, the analytical models offer a quick and reasonable estimate of annual runoff characteristics $(\mathrm{Li}, 1997)$. The $\zeta$ values for of a number of Canadian rain stations was compiled by Kauffman (1987).

A multi-efficiency model is used to estimate the cumulative runoff volume $\left(N_{v}\right)$ and solids loading $\left(N_{s}\right)$ reduction efficiencies of a series of RSWMPs:

$$
\begin{aligned}
& N v=\left[1-\prod_{i}^{n}\left(1-\eta_{v}\right)\right] * 100 \% \\
& N_{s}=\left[1-\Pi_{i}^{n}\left(1-\eta_{v}\right)\left(1-\eta_{s}\right)\right] * 100 \%
\end{aligned}
$$

where:

$$
\begin{aligned}
i= & \mathrm{i}^{\text {th }} \text { RSWMP, } \\
n= & \text { total number of RSWMPs, } \\
\eta_{v}= & \text { runoff volume reduction efficiency of an RSWMP, } \\
& \text { and } \\
\eta_{s}= & \text { solids concentration reduction efficiency of an } \\
& \text { RSWMP. }
\end{aligned}
$$

For RSWMPs which reduce solids concentration only (e.g. oil/grit separators, ponds), $\eta_{v}$ is zero. For RSWMPs which reduce runoff volume only (e.g. downspout disconnection, stormwater exfiltration systems), $\eta_{s}$ is zero. For newly developed RSWMPs which have not been proven by rigorous field monitoring, the $\eta_{v}$ or $\eta_{s}$ values used in Equations (8.3) and (8.4) may be based on conservative estimates of their control potential or computer model simulation results.

A planning area is first divided into a number of subcatchments. The runoff volume and solids concentration reduction efficiencies of RSWMPs at each subcatchment are determined as follows.

\section{Downspout disconnection}

Runoff volume reduction efficiency $\left(\eta_{v}\right)$ is given by:

$$
\eta_{\nu}=\left[1-\frac{R s}{R e}\right] * 100 \%
$$

where:

$$
\begin{aligned}
& R_{s}=\begin{array}{l}
\text { average annual runoff volume after the application of } \\
\text { downspout disconnection, and }
\end{array} \\
& R_{e}=\text { existing average annual runoff volume. }
\end{aligned}
$$


For downspout disconnection, the existing impervious area of a subcatchment is reduced by the equivalent disconnected roof area. The revised area-weighted runoff coefficient and depression storage are used to calculate the revised annual runoff volume (i.e. $R_{s}$ ) of the subcatchment. The runoff volume reduction efficiency of the subcatchment is then determined using Equation (8.5).

\section{Oil/grit separators}

The solids concentration reduction efficiency for a subcatchment $\left(\eta_{s}\right)$ is given by:

$$
\eta_{s}=\eta_{s a} * \frac{R_{a}}{R_{c}}
$$

where:

$$
\begin{aligned}
\eta_{s a}= & \text { solids concentration reduction efficiency of oil/grit } \\
& \text { separators, } \\
R_{a}= & \text { average annual runoff volume from the area served by } \\
& \text { oil/grit separators, and } \\
R_{c}= & \text { average annual runoff volume from the subcatchment. }
\end{aligned}
$$

Both $R_{a}$ and $R_{c}$ are determined using Equation (8.1).

\section{Stormwater exfiltration systems}

The runoff volume reduction efficiency for a subcatchment $\left(\eta_{v}\right)$ is given by:

$$
\eta_{v}=\eta_{v a} * \frac{R_{a}}{R_{c}}
$$

where:

$$
\begin{aligned}
\eta_{v a}= & \text { runoff volume reduction efficiency of stormwater } \\
& \text { exfiltration systems, } \\
R_{a}= & \text { average annual runoff volume from the area served by } \\
& \text { stormwater exfiltration system, and } \\
R_{c}= & \text { average annual runoff volume from the subcatchment. }
\end{aligned}
$$

Both $R_{a}$ and $R_{c}$ are determined using Equation (8.1).

Quantity pond retrofit, new quality ponds, underground stormwater quality tanks/tunnels, and Karl Dunkers Flow Balancing Systems

The solids loading reduction efficiency for a subcatchment is determined in a manner similar to that of oil/grit separators.

The average annual runoff volume $\left(R_{n}\right)$ and solids loading $\left(L_{n}\right)$ after the application of a series of RSWMPs are determined by: 


$$
\begin{aligned}
& R_{n}=R * N_{v} \\
& L_{n}=L * N_{s}
\end{aligned}
$$

where $R$ and $L$ are the existing annual runoff volume and solids loadings.

Finally, the cumulative runoff volume and solids loading reduction can be determined by aggregating the $R_{n}$ and $L_{n}$ values of all the subcatchments and dividing them by the corresponding $R$ and $L$ values before any RSWMPs are applied. Unit cost (without land costs) functions of RSWMPs are used to determine the cost of RSWMPs for each subcatchment and the planning area. The marginal cost of RSWMPs is defined as the cost per percent of runoff volume or solids loading reduction.

The evaluation of the runoff control effectiveness and cost of RSWMPs is subject to uncertainties both in model selection and parameter estimation. The uncertainty of model selection was not analyzed explicitly in this study due to time constraints. However, the analytical probabilistic models (Adams and Bontje 1983) had been compared extensively with the continuous STORM model (HEC, 1974) and the analysis results of both models were generally found to be in good agreement (Kauffman, 1987). The uncertainty of parameter estimation can be addressed by a sensitivity analysis which investigates the change in runoff control cost and performance of RSWMPs with respect to the variation of cost and performance parameters.

ALOTUS 1-2-3 spreadsheet program, based on the analytical probabilistic models (Adams and Bontje, 1983) and a multi-efficiency model (Weatherbe, 1995), has been coded to determine the following items for each subcatchment as well as the planning area:

- the existing average annual runoff volume $\left(\mathrm{m}^{3} / \mathrm{yr}\right)$ and solids loading $(\mathrm{kg} / \mathrm{yr})$;

- the runoff volume and solids concentration reduction efficiencies (\%) of RSWMPs;

- the cumulative runoff volume and solids load reduction efficiencies (\%) of a series of RSWMPs;

- the average annual runoff volume and solids loading after the application of each RSWMP;

- the cost of runoff volume and solids loading reduction for each RSWMP;

- the marginal cost of runoff volume and solids load reduction for each RSWMP; and

- the cumulative cost of runoff volume and solids loading reduction for a series of RSWMPs. 
Using this spreadsheet program, the RSWMP's control performance and cost for each municipality within the Mimico Creek watershed were determined. Tables 8.3 to 8.5 show the control performance and cost for each of the cities in the Mimico Creek watershed.

Table 8.3 Control performance and cost for retrofit strategies in the City of Toronto.

\begin{tabular}{|c|c|c|c|c|c|c|c|}
\hline Strategy & $\begin{array}{l}\text { Downspout } \\
\text { disconnection } \\
\text { cost } \\
(C \$ 1000)\end{array}$ & $\begin{array}{l}\text { Oil/grit } \\
\text { separator } \\
\text { cost } \\
(\mathrm{C} \$ 1000)\end{array}$ & $\begin{array}{l}\text { Exfiltration } \\
\text { system } \\
\text { cost } \\
(C \$ 1000)\end{array}$ & $\begin{array}{l}\text { New } \\
\text { quality } \\
\text { ponds cost } \\
(C \$ 1000)\end{array}$ & $\begin{array}{l}\text { Overall \% } \\
\text { annual runoff } \\
\text { reduction for } \\
\text { Toronto }\end{array}$ & $\begin{array}{l}\text { Overall \% } \\
\text { Annual } \\
\text { solids } \\
\text { Reduction }\end{array}$ & $\begin{array}{l}\text { Overall total } \\
\text { cost } \\
\text { (C\$million) }\end{array}$ \\
\hline S1a & 17 & $\mathrm{n} / \mathrm{a}$ & $\mathrm{n} / \mathrm{a}$ & $\mathrm{n} / \mathrm{a}$ & $4 \%$ & $19 \%$ & 0.02 \\
\hline S1b & 17 & $\mathrm{n} / \mathrm{a}$ & $\mathrm{n} / \mathrm{a}$ & 126 & $4 \%$ & $23 \%$ & 0.14 \\
\hline $\mathrm{S} 2 \mathrm{a}$ & 172 & $\mathrm{n} / \mathrm{a}$ & 6053 & $\mathrm{n} / \mathrm{a}$ & $14 \%$ & $27 \%$ & 6.22 \\
\hline $\mathrm{S} 2 \mathrm{~b}$ & 172 & 885 & 6053 & 791 & $14 \%$ & $30 \%$ & 7.90 \\
\hline S3a & 429 & $\mathrm{n} / \mathrm{a}$ & 7321 & $\mathrm{n} / \mathrm{a}$ & $17 \%$ & $29 \%$ & 7.75 \\
\hline $\mathrm{S} 3 \mathrm{~b}$ & 429 & 1327 & 7321 & 953 & $17 \%$ & $33 \%$ & 10.03 \\
\hline
\end{tabular}

Table 8.4 Control performance and cost for solids loading reduction in the cities of Brampton and Mississauga.

\begin{tabular}{lcccc}
\hline Municipality & $\begin{array}{c}\text { Oil/grit } \\
\text { separator cost } \\
\text { (C\$million) }\end{array}$ & $\begin{array}{c}\text { New quality } \\
\text { pond cost } \\
\text { (C\$1000) }\end{array}$ & $\begin{array}{c}\text { Overall \% annual } \\
\text { solids reduction } \\
\text { for each city }\end{array}$ & $\begin{array}{c}\text { Overall total } \\
\text { cost } \\
\text { (C\$million) }\end{array}$ \\
\hline Brampton & 5.6 & 328 & $9 \%$ & 6.0 \\
Mississauga & 3.2 & 68 & $6 \%$ & 3.3 \\
\hline
\end{tabular}

Table 8.5 Stormwater retrofit performance and cost for the Mimico Creek watershed.

\begin{tabular}{lccc} 
Municipality & $\begin{array}{c}\% \text { annual runoff } \\
\text { volume reduction }\end{array}$ & $\begin{array}{c}\% \text { annual solids } \\
\text { loading reduction }\end{array}$ & $\begin{array}{c}\text { Total cost } \\
\text { (C\$million) }\end{array}$ \\
\hline Toronto & $17 \%$ & $33 \%$ & 10.0 \\
Brampton & $0 \%$ & $9 \%$ & 6.0 \\
Mississauga & $0 \%$ & $6 \%$ & 3.3 \\
Total watershed & $7 \%$ & $18 \%$ & 19.3 \\
\hline
\end{tabular}

The cost-effectiveness of RSWMPs was investigated by comparing the marginal costs of quality control as indicated in Table 8.6. The marginal costs of solids loading reduction for downspout disconnection, and new quality ponds are generally lower than those of the other RSWMP's, and oil/grit separators are the least cost-effective. In the Mimico Creek watershed, the descending order of cost-effectiveness is: (i) downspout disconnection; (ii) water quality ponds; (iii) stormwater exfiltration systems; and (iv) oil/grit 
Table 8.6 Marginal costs of solids loading reduction.

\begin{tabular}{lc}
\hline RSWMPs & Marginal cost of solids loading reduction \\
\hline Downspout disconnection & $\mathrm{C} \$ 43 / \mathrm{kg}$ \\
Water quality ponds & $\mathrm{C} \$ 44 / \mathrm{kg}$ \\
Exfiltration systems & $\mathrm{C} \$ 98 / \mathrm{kg}$ \\
Oi1/grit separators & $\mathrm{C} \$ 213 / \mathrm{kg}$ \\
\hline
\end{tabular}

separators. Thus, the sequence of RSWMP implementation should follow the descending order of cost-effectiveness.

\subsubsection{Selection of the Preferred Retrofit Strategy}

Currently, most of the municipal capital and operating projects in the Mimico Creek watershed, such as road and sewer reconstruction or rehabilitation, are developed without consideration for stormwater quality improvement. Examining the marginal costs of RSWMPs, there is a sequence of actions that the municipality may consider for implementation:

- The appropriate residential areas should have downspouts disconnected gradually. Ways to achieve a higher percent coverage for downspout disconnection should also be investigated, including combinations of subsidies, regulatory measures and application of additional technologies such as rain barrels and soak-away pits.

- New water quality ponds identified in strategies should be investigated further in detail. As land is redeveloped in the watershed, additional stormwater quality ponds should be considered as part of the redevelopment requirements.

- In the long term, performance and maintenance data may validate the effective use of stormwater exfiltration systems on roads/ sewers. All the appropriate roads/sewers identified to be in poor condition currently should be retrofitted with stormwater exfiltration systems. Other appropriate roads which are identified to be in good condition currently should be retrofitted as they are reconstructed or rehabilitated in the next 25 years.

- In order to improve the water quality control level, operational controls, such as improved sweeping practices (e.g. switch to vacuum sweepers and increase frequency) and increased catch basin sump maintenance and sewer cleaning, and management practices, such as education and by-law enforcement, should be examined and applied appropriately. 
- Existing ditches and swales should be preserved, as their water quality treatment benefits are important in controlling runoff volume and quality. Conversion of ditches and swales to storm sewers may reduce the overall water quality improvement of RSWMPs.

- A methodology for measuring the benefits of RSWMPs on receiving water should be developed. For example, continuous field monitoring programs should be established to measure chemical and biological parameters downstream of the RSWMPs.

- The stormwater quality management strategies should be reviewed and updated periodically as part of the Capital Budget Process.

\subsection{Conclusions}

One of the many challenges that municipalities must face, in particular, is the lack of a stormwater quality management planning tool for existing urbanized areas. A stormwater retrofit planning tool developed by Li and Banting (1999) allows users to (i) identify appropriate RSWMPs; (ii) estimate the potential cumulative effectiveness and costs of RSWMP; (iii) develop and evaluate alternative stormwater retrofit strategies; and (iv) select the preferred strategy for short and long term implementation. As demonstrated in the Mimico Creek watershed study, this planning tool can be easily applied by municipal staff and factored into municipal capital works and maintenance planning process. Future technology development of RSWMP should take into consideration the potential to integrate with muncipal capital works and maintenance activities such as road and sewer reconstruction and rehabilitation. Although downspout disconnection and water quality ponds are both cost-effective, downspout disconnection may be a preferred option for municipal application as it can be applied gradually over a long period time.

\section{References}

Adams, B.J. and Bontje, J.B. 1983. Microcomputer applications of analytical models for urban drainage design. Proc., Emerging Computer Techniques for Stormwater and Flood Management, ASCE.

Aquafor Beech Ltd. 1994. Environmental Study Report Brimley Road Drainage Area - Water Quality Enhancement Strategy. Report prepared for the City of Scarborough, Ontario, Canada.

Dunkers, K. 1979. Plate settling in crossflow. Pamphlet No. 79-01, Sweden. 
Hydrologic Engineering Center (HEC). 1974. Manual of the Storage, Treatment, Overflow and Runoff Model (STORM). U.S. Corps of Engineer.

Huber, W.C. and Dickinson, R.E. Storm Water Management Model, Version 4: User's Manual. U.S. EPA, Athens, Georgia, 1988

Kauffman, G. 1987. A comparison for analytical and simulation models for drainage system design: SUDS versus STORM. MASc Thesis, University of Toronto, Toronto, Ontario, Canada.

Li, J., Tran, J., Henry, D., and Liang, W. 1997. Development and Evaluation of the City of Etobicoke Exfiltration System. Proc. of the Operational Water Management Conference, European Water Resources Association, Copenhagen, Denmark, 407-413.

Li, J., R. Orland, and T. Hogenbirk. 1998. Environmental Road and Lot Drainage Designs: Alternatives to the Curb-Gutter-Sewer System. Canadian Journal of Civil Engineering, 25(1):26-39.

Li, J. 1997. A Planning Tool for Stormwater Quality Management in Urbanized Areas. Report prepared for Great Lakes Cleanup Fund, Environment Canada, Burlington, Ontario, Canada.

Li, J. and Banting, D. 1999. A Storm Water Retrofit Plan for the Mimico Creek Watershed. Water, Science and Technology, Int'l Assoc. of Water Quality, 39(12):133-140.

Ministry of Environment and Energy (MOEE). 1994. Stormwater Management Practices Planning and Design Manual. Queen's Printer of Ontario, Toronto, Ontario, Canada.

Paul Theil Associates Ltd. 1991. Feasibility Study of the Dunkers Flow Balancing System. Report prepared for the City of Scarborough, Ontario, Canada.

J.F. Sabourin, and Associates Inc. 1997. Evaluation of Roadside Ditches and Other Related Stormwater Management Practices. Report prepared for the Metroplitan Toronto and Region Conservation Authority, Toronto, Ontario, Canada

Toronto and Region Conservation Authority (TRCA). 1998. State of the Watershed Report: Etobicoke and Mimico Creek. Reported prepard for TRCA, Toronto, Ontario, Canada.

Tran, J. 1994. Motel strip stormwater management plan. Report prepared for the City of Etobicoke, Ontario, Canada.

Weatherbe, D.G. 1995. Laurel Creek analysis - phosphorus. Report prepared for the Grand River Conservation Authority, Ontario, Canada. 